\title{
Reports, Forum
}

Monika Wiertek, Monika Winiarska

Pontifical University of John Paul II in Krakow, Poland

\section{The Pontifical University of John Paul II in Krakow http://upjp2.edu.pl/}

\section{History}

The history of the Pontifical University of John Paul II in Krakow can be traced back to the same time as the beginnings of the oldest Polish higher education institution - the Jagiellonian University. In 1397 Pope Boniface IX decreed the establishment of the Faculty of Theology within the Studium Generale. Since then the Faculty developed and operated actively for centuries, gaining fame and respect in the scientific community, both in Poland and abroad. An attempt at stopping its operations was made by the Communist authorities when in 1954 the Faculty of Theology was liquidated at the Jagiellonian University by way of a unilateral decision of the Council of Ministers. However, that decision did not interrupt its activity or canonical existence.

The contribution of Blessed John Paul II must be stressed here as in the times when he was still Cardinal Karol Wojtyła. His efforts were instrumental to make our university survive and develop in these hard times. He had ties with the Faculty of Theology earlier, in the times of the occupation of Poland, through his theological and philosophical studies, and later through his doctoral and habilitation dissertation. It was thanks to his efforts that in 1974 the Faculty received the honourable name of the Pontifical Faculty and on $8^{\text {th }}$ December 1981 it was transformed into the Pontifical Academy of Theology in Krakow by him as Pope John Paul II. The Academy consisted of 3 faculties: the Faculty of 
Theology, the Faculty of Philosophy and the Faculty of Church History. The title of the university was granted in 2009 when Pope Benedict XVI changed the name of the Pontifical Academy of Theology in Krakow to the Pontifical University of John Paul II in Krakow in honour of his predecessor.

The Pontifical University of John Paul II is a dynamically developing higher education institution. Our educational offer is interesting for young people. In our five faculties, we constantly open new majors and specialisations, keeping up with the needs of the present times. We constantly establish new international contacts. Our students are also given opportunities to develop their passionate interests. There are numerous student research circles operating at our university, a university library with an excellent collection, Bonus radio station using a professional recording studio, the successful Psalmodia choir... any many more opportunities.

The tradition we are rooted in obliges us to care for the high quality of education and taking new research challenges, according to the thoughts of our patron, Blessed John Paul II who emphasised a positive role of the Church for culture and education and attached great importance to the dialogue with the scientific world. We hope that in the future the Pontifical University will play a role in preserving the European identity by strengthening relations between science and faith in the spirit of the encyclical Fides et ratio and reminding us about the Christian roots of the European culture.

\section{Majors facts, dates, events}

12 May 1364 - King Casimir the Great issued the charter of foundation of the Studium Generale, which gave birth to the Krakow Academy

11 January 1397 - Pope Boniface IX decreed the establishment of the Faculty of Theology

1400 - The Academy resumed its activity thanks to the personal efforts and financial support of Saint Jadwiga, Queen of Poland. Since then it has functioned under the name Jagiellonian University

1954 - The Council of Ministers of the People's Republic of Poland removed the

Faculty of Theology from the Jagiellonian University

1974 - The Pontifical Faculty of Theology was founded in Krakow

8 December 1981 - Pope John Paul II established the Pontifical Academy of Theology in Krakow 
19 June 2009 - Pope Benedict XVI changed the rank of the former Pontifical Academy of Theology to the rank of the Pontifical University of John Paul II

\section{The University today}

Studying in Krakow is a unique opportunity for our students to have a close contact with culture and science in one of the most beautiful cities of Europe and a guarantee of both spiritual as well as intellectual development. We offer classes in small groups, which are conducive to good relations between students and lecturers, and treating each person individually.

The unique aspect of our University is the combination of the atmosphere of faith and tradition of the Catholic Church with the modern form of studies. The University realises its educational and academic activities within five faculties: the Faculty of Philosophy, the Faculty of History and Cultural Heritage, the Faculty of Social Sciences, the Faculty of Theology and the branch campus of the Faculty of Theology - Theological Section in Tarnów. Research is also conducted within interdepartmental Institutes of Bioethics and of Ecumenism and Dialogue, and at the Centre of Research on John Paul II's Thought. As a result of cooperation with Krakow's universities, two interuniversity entities were established. The Copernicus Centre for Interdisciplinary Studies is the effect of cooperation between the Jagiellonian University and the Pontifical University of John Paul II while the Interuniversity Institute of Church Music was established thanks to the contract of 2008 with the Academy of Music in Krakow.

The University belongs to the International Federation of Catholic Universities (FIUC) and its European section (FUCE), the University Network of the European Capitals of Culture (UNEECC), the Conference of Rectors of Polish Universities (KRUP - regulations of KRUP) and the Conference of Rectors of Academic Schools in Poland (KRASP).

\section{Open university}

\section{Open lectures}

For many years the University has organised open lectures which have gained huge popularity. 
The Bible in the World Culture - Department of Theology and Biblical Information Technology and the Department of Marriage and Family (Faculty of Theology).

John Paul II. Ministry of Thinking - Centre of Research on John Paul II's Thought.

Seminars on Natural Philosophy - Copernicus Centre for Interdisciplinary Studies.

Symbol - Sign - Message - Department of Auxiliary Sciences of History and Archival Science (Faculty of History and Cultural Heritage).

\section{Workshops}

The Faculty of History and Cultural Heritage organises History Workshops for Teenagers. Free workshops are conducted in a varied form of lectures, workshops and trips by the academic staff of the Pontifical University of John Paul II. They are committed to expand the knowledge of selected events from the history of Poland and the world, with particular emphasis laid on the influence of Christianity on the historical and cultural landscape of Europe.

\section{Camps and scientific trips}

Our students take part in scientific trips and training, which form an integral part of their educational process, especially in such majors as History and History of Art. These trips are mostly to Mediterranean countries but also to Eastern Europe, France, Great Britain and other places.

For more than ten years, the Department of Theology and Biblical Information Technology (Faculty of Theology) has been organising Biblical and archaeological camps every summer. The majority of camps were held in Israel. The Department has also organised trips to Turkey and Berlin.

\section{University of the Third Age}

University of the Third Age is a proposal of the Pontifical University of John Paul II aimed at people at the age of 50+ who ended their professional activity but still want to develop intellectually and spiritually. U3A is an initiative which we undertook bearing in mind the needs of elderly people, who are often alone. This project is to assure their intellectual activation, the creative use of their free time, the counteracting of loneliness and motivation for further religious development. 
U3A offer involves lectures, classes and seminars in philosophy, psychology, history, social science, ethics and theology. Additionally, students may take part in pilgrimages, trips, retreats, academic conferences and cultural events.

\section{The John Paul II Days}

John Paul II Days is an initiative which commemorates Pope John Paul II and popularises his heritage among the academic community of Krakow and Małopolskie province. The decision to organise the first John Paul II Days was made by Kolegium Rektorów Szkół Wyższych Krakowa (Collegium of Rectors of Krakow Academies). Krakow's higher education institutions as well as other academies from Małopolskie province took part in this project. Their actions with the motto "Truth" were coordinated by the then Pontifical Academy of Theology in Krakow. Others among Krakow's higher education institutions then took charge of the coordination consecutively.

\section{Tischner's Days}

Tischner's Days is an initiative of the Pontifical University of John Paul II and other cultural and academic institutions associated with a Professor of our Academy, Rev. Józef Tischner. This festival is aimed at promoting and developing Tischner's philosophical ideas. The offer of Tischner's Days (panel discussions with outstanding scientists, lectures, exhibitions, performances) attracts many participants every year.

\section{The Role of the Catholic Church in the process of European integration}

The conferences devoted to the role of the Catholic Church in the process of European integration are organised yearly by the Pontifical University of John Paul II in cooperation with the Konrad-Adenauer-Stiftung in Poland, the Robert Schuman Foundation of Luxembourg and the Fraction of the European People's Party at the European Parliament. These conferences are aimed at a public debate on the role of a Christian politician in uniting Europe. Their high substantive level and prestige attract numerous outstanding politicians and social activists, important figures of the Church and a large group of guests, including guests from abroad. 


\section{The Structure of the University}

\section{The Faculty of Philosophy}

Research as well as academic and educational work are carried out in thirteen departments covering a wide array of the areas of modern philosophy: from ethics, bioethics, human philosophy, metaphysics, philosophy of religion, through logic, philosophy of science to philosophy of physics and cosmology. Thanks to the departments' international contacts, they can invite well-known philosophers to deliver lectures. The strong foundation on the Western Christian tradition, including Thomism and Augustinianism, enables the courageous use of modern philosophical trends, among which the most significant role is played by the philosophy of language, analytical philosophy, phenomenology and hermeneutics. The figures of two outstanding philosophers: Rev. Prof. Józef Tischner and Rev. Prof. Michał Heller are closely associated with this Faculty. Three academic periodicals are regularly published under the auspices of the Faculty: Logos i Ethos, Zagadnienia Filozoficzne w Nauce, Racjonalia. Z punktu widzenia humanistyki and Semina Scientarium. The Centre for Interdisciplinary Studies also operates within the Faculty.

\section{The Faculty of History and Cultural Heritage}

The initial Faculty of Church History was transformed in 2008 into the Faculty of History and Cultural Heritage. Currently it consists of the Institute of History, the Institute of the History of Art and Culture and the Interuniversity Institute of Church Music. The aim of the Faculty is to research and propagate the knowledge about the history of Church, with particular emphasis on its role in the history and culture of the Slav nations, mostly Poland. Since 2007 the Inventory Workshop has operated within the Faculty and since 2008 the Research Workshop on the History and Culture of Totalitarian and Post-Totalitarian Space. The Faculty publishes Folia Historica Cracoviensia journal.

\section{The Faculty of Social Studies}

The objective of the Faculty is the versatile and systematic examination of social issues in the light of contemporary legal conditions and research. Lecturers and students are committed in their involvement in research on the social condition of contemporary civilisation in the light of Catholic social science. Since 2009, the Faculty has been composed of the Institute of Family Studies and the Institute of Journalism and Social Communication. "Radio Bonus" established on 2 
April 2010 is run by the students of journalism who use a professional emission and recording studio, an editing post and modern reporting equipment. A lot of materials are prepared in the studio, including materials presenting the life of the University but also for institutions the Radio cooperates with, e.g. for the Vatican Radio and the Catholic Information Agency (KAI). The Faculty's academic journal is a half-yearly magazine, Studia Socialia Cracoviensia, covering the problems of research in the field of media, journalism, social communication, the family, social policy, family policy, and social and civilisation issues.

\section{The Faculty of Theology}

The Faculty of Theology constitutes the foundation of the University and a kind of a bridge between history and contemporaneity. The Faculty was established as a result of the efforts of Saint Jadwiga of Poland, during the reform of the Krakow Academy in 1397. It was connected with the Jagiellonian University until 1954 when the Communist authorities repressed this faculty of the Jagiellonian University and ordered it to transfer itself to Warsaw, thus founding the Academy of Catholic Theology. But the Faculty remained in Krakow and even though it had no rights, it continued its operation which was limited to educating seminarians preparing themselves for the priesthood. In 1974 it took the name of the Pontifical Faculty of Theology and later became the foundation of the Pontifical Academy of Theology in Krakow. The Faculty of Theology cooperates with numerous academic centres in Poland and abroad, e.g. theological education centres in Ukraine and Slovakia. Within the Faculty's publishing activity, numerous scientific and popular scientific publications are issued. Other publication of the Faculty are entitled Polonia Sacra, Theological Research, Annales Canonici (annals of the Institute of Canon Law) and Arché Studia Teologiczno-Filozoficzne.

\section{The Faculty of Theology Section in Tarnów}

The Faculty of Theology Section in Tarnów was established as a result of the transformation of the Institute of Theology in Tarnów founded in 1822. Currently, the Faculty operates as a branch campus of the Pontifical University of John Paul II, basing itself on the economic and material resources of the Higher Theological Seminary in Tarnów. The academic staff conducts research within ten of the Faculty's institutes and in collaboration with scientific centres in Poland and abroad. The results of research are published in various scientific publications: monographs, academic series and articles. The Faculty publishes its half-yearly magazine Tarnowskie Studia Teologiczne and an international periodical The Person and the Challenges. 


\section{The Institute of Canon Law at the Faculty of Theology}

It was established by a decree of the Holy See in 1999. The Institute has the right to grant the degree of bachelor in canon law which is necessary for holding most official positions in ecclesiastical tribunals and to deliver lectures on canon law in theological seminaries. Studies at the Institute also prepare future candidates for positions in church administration or parish counselling centres. The Institute publishes the legal annual Annales Canonici which treats the Church's legislative activity and presents the latest achievements in canon law.

\section{Interuniversity entities}

\section{The Copernicus Centre for Interdisciplinary Studies}

This is an interuniversity institution (a joint entity of the Pontifical University of John Paul II and the Jagiellonian University). It was established as a result of the award to Rev. Prof. Michał Heller of the prestigious Templeton Prize for Progress towards Research or Discoveries about Spiritual Realities in 2008. An important element of the Centre's functioning is constituted by Krakow's Methodological Conferences initiated by the Centre for Interdisciplinary Studies, which attract an increasing number of participants from all over Poland and some outstanding figures from the world of science, including foreign authorities. What characterises these conferences is the dialogue and strong interaction between philosophers and representatives of science and mathematics.

\section{The Interuniversity Institute of Church Music}

On 1 February 2008 the Ministry of Science and Higher Education approved the major of Church Music for two higher education institutions cooperating in this respect: the Pontifical University of John Paul II and the Academy of Music in Krakow. The Institute publishes the magazine Pro Musica Sacra. The Interuniversity Institute of Church Music is in the possession of the largest mechanical organs in Krakow.

\section{Interdepartmental entities}

\section{The Interdepartmental Institute of Bioethics}

It was founded by the University's Senate in 1988. The Institute conducts ethical research on medical and non-medical interference with human life from conception to death, and finds its inspiration from the documents of the Magisterium of the Church, with the use of contemporary knowledge of biology, embryology, genetics and biotechnology. The Institute also offers post-graduate education. 


\section{The Interdepartmental Institute of Ecumenism and Dialogue}

It was founded by the University's Senate in 1993. The objective of the Institute is to facilitate the openness of the University to ecumenical dialogue. Apart from making available the fruit of the University's activity to the scientific communities from beyond the circles of the Roman Catholic Church, the Institute also creates the conditions for the right course of studies for students belonging to other Christian churches or religious communities or having a different philosophy of life but are interested in studying Catholic theology, the history of the Church or Christian philosophical thought. The Interdepartmental Institute of Ecumenism and Dialogue organises a monograph lecture $A B C$ of Christian, Polish and Jewish Relations in cooperation with the Higher Theological Seminary of the Krakow Archdiocese and the Ministry of Foreign Affairs; its task also includes the promotion of knowledge on relations between Christianity and Judaism, the theology of Christian and Jewish dialogue, and Polish and Israeli relations. The Institute publishes the series Biblioteka Ekumenii i Dialogu. It is also the coorganiser of the Week of Prayer for Christian Unity, the Day of Judaism and the Day of Islam in the Catholic Church in Poland.

\section{The Centre of Research on John Paul II's Thought}

It is involved in presenting and developing John Paul II's philosophy and theology through detailed studies, publications and the organisation of symposia and interdisciplinary seminars. The Centre seeks to integrate the initiatives existing at the University and numerous research projects in the field of John Paul II's thought. The Centre cooperates with research centres, institutions and social initiatives that promote and develop John Paul II's intellectual heritage. Open lectures: John Paul II. Ministry of Thinking. Series: Studies on John Paul II's Thinking. Proseminar on John Paul II's feminism: "kobieta21".

\section{The University Library}

The library is among the largest church libraries in Poland. It gives basic academic and educational background to the University's professors and students. The University library network involves the main library, the libraries of the various faculties, the institute libraries and book collections of particular departments.

more than 7,200 readers

four reading rooms 
free Internet access

collection - half a million volumes, 4,600 magazine titles, including about 2,500 foreign magazine

8,000 old prints

The collection has been gradually increasing by about $25,000-30,000$ volumes a year. Since 1995 the Library has used an integrated computer library system VTLS/Virtua within the Krakow Library Complex. The Library has also actively participated in the formation of the Polish national computer library catalogue NUKAT since 2000. It is the founder of the Polish Federation of Church Libraries FIDES and the Polish Internet Library. The Library's new building has the usable space of almost $9,000 \mathrm{~m}^{2}$. The Library has more than 250 research/study places in reading rooms, 15 separate rooms for individual work, a conference room with 108 seats and three rooms for team work.

\section{Students}

Our students can develop their interests and passions in many student organisations and research circles:

- Student Self-government,

- PATMOS Student Catholic Ministry Centre,

- Academic Circle of Volunteer Service Caritas,

- Psalmodia Choir,

- Bonus Radio,

- Journalism Research Circle,

- Research Circle of Christian Archaeologists,

- Research Circle of History Students,

- Research Circle of Students from Eastern Europe,

- Research Circle of Philosophy Students,

- Research Circle of the Students of the History of the Arts,

- Research Circle of the Students of the Interuniversity Institute of Church Music,

- Research Circle of Theologians. 


\section{Psalmodia Choir}

The choir was established in 1988 and it actively participates in all celebrations of the Pontifical University, the city of Krakow and the Church in Krakow. "Psalmodia" choir also cooperates with the Polish Radio Choir in Krakow, the Krakow Opera, the Krakow Philharmonic and TVP (Polish television). The choir has gone on many tours in Poland and abroad, e.g. in Italy and Sweden. In 2009 "Psalmodia" won the first place in the category of mixed choirs at the $4^{\text {th }}$ "Cantate Domino" Choir Festival.

\section{Erasmus}

Our University has participated in this programme since the academic year 2008/2009, thus making it possible for students, PhD students and academic staff to gain international experience and extra competence during scholarship programmes. The Erasmus programme has considerably contributed to the animation of our international cooperation. Currently, we maintain contacts with 15 partner universities. We are also negotiating other exchange programme options.

The University cooperates with the following foreign institutions:

- Albert-Ludwigs-Universität Freiburg,

- Danmark Medieog Journalisthojskole Arhus,

- Katolicka univerzita v Ružomberku,

- Ostravská univerzita v Ostravě,

- Prešovská univerzita v Prešove,

- Theologische Fakultät Trier,

- Universidad de Navarra,

- Università degli studi di Trento,

- Università degli Studi di Verona,

- Université Catholique de Lille,

- Université de Fribourg,

- Univerza v Ljubljani,

- Univerzita Karlova v Praze,

- Univerzita Komenskeho v Bratislave,

- Vilnius University. 